\title{
PLANTS AND MUSHROOMS IN THE MANAGEMENT OF DIABETES
}

Ishawu Iddrisu', Prince Chikwere ${ }^{2}$

${ }^{1}$ Cancer Research, African Cancer Organization, Accra, Ghana; ish.nutrist@gmail.com

${ }^{2}$ Department of Nursing, All Nations University College, Koforidua, Ghana; uc.princechik@gmail.com

Correspondence: uc.princechik@gmail.com 


\section{ABSTRACT}

The management of diabetes is crucial since that is the only option for this chronic noncommunicable disease. The administration of medicinal drugs for the management of diabetes is critical. It is however important to note that some plants have components that confer anti-diabetic properties and may be of use especially in developing countries where there is limited access to healthcare. The aim of this review is to review studies that involved plants with anti-diabetic effects. Such plants as tea, mushroom, broccoli, garlic, moringa, ginseng, guava, onion, tiger nut, bush mango, okra, dates, bitter melon, dandelion, watermelon, and pumpkins may reduce diabetes risks, or even lower blood glucose in diabetes patients (notably type 2 diabetes). Phytoremediation via plant foods should not be underestimated in the management of diabetes.

KEYWORDS: diabetes, plants, mushroom, preventive, anti-diabetic

\section{INTRODUCTION}

Diabetes is a metabolic disorder characterised by high blood glucose concentrations due to disorder in insulin production, secretion or action. There are two major types of the disorder: type 1 diabetes, caused by absolute insulin deficiency and type 2 diabetes, caused by progressive insulin secretory defect or insulin resistance. The non-drug approach to the treatment of diabetes is very important and useful, particularly to people in developing areas where access to healthcare is a challenge (O'Donnell, 2007). For several centuries now, herbs, plants and plant extracts have been used as food and for the treatment of many diseases. Most of these plants have been studied for their medicinal properties. For the use of these plants in the treatment of diabetes, this paper looked at several of the plants and extracts with documented evidence of treating diabetes. Many plants have been used in the Indian population, not only as food but also for the treatment of diabetes, of which most of these plants and plant extracts have been proven to contain substances that inhibit Human Pancreatic Amylase (Ponnusamy et al., 2011). This review covers several selected plants and plant extracts that have been used in the Indian Ayurveda system, in Chinese traditional medicine, and in Africa to review their potential anti-diabetic properties. Table 1 shows a summary of all selected plants, plant extracts and mushroom that have antidiabetic effects in diabetic patients and rats. These are substances that have exhibited potential in preventing the occurrence of diabetes or to slow down its development and possible complications.

It is estimated that over 200 species of plants exhibit anti-diabetic (hypoglycaemic) properties (Jia et al., 2003). The purpose of this review is not to promote products that contain these plant foods or herbs but to present available literature on the importance of these plants in the fight against diabetes.

\section{ANTI-DIABETIC EFFECTS OF SELECTED PLANTS AND MUSHROOM}

\section{Green Tea}

Green tea comes from the plant, Camellia sinensis. Tea consumption has been linked to reduced risk or reduced incidence of type 2 diabetes (The Inter Act Consortium, 2012). This protective effect may be attributed to the flavonoids contained in tea (Kao et al., 2006). Moderate- to long-term tea 
consumption is associated with a lower incidence of type 2 diabetes and has a significant reductive effect on fasting blood glucose levels in type 2 diabetic patients (Panagiotakos et al., 2009). Several human and animal studies suggest that green tea has a blood glucose-lowering effect in diabetic patients (Panagiotakos et al., 2009; Igarashi et al., 2007; Wolfram et al., 2006; Sabu et al., 2002). Haidaria et al. (2013) also reported that administration of green tea orally brought serum glucose levels to normal and the glycaemic control was improved upon oral administration of green tea extract. Green tea has also been shown to have a glycaemic regulation effect even in pre-diabetic patients (Toolsee et al., 2013). It also has a protective effect against diabetic nephropathy in type 2 diabetes patients (Kang et al., 2012). However, Mackenzie et al. (2007) did not find any significant hypoglycaemic effect of either green or black tea in type 2 diabetes in adults with a median diabetes duration of 6 years. This suggests that green and black tea could significantly reduce blood glucose levels for newly diagnosed diabetics. This is probably so because newly diagnosed diabetic patients' systems might be able to respond to green or black tea more effectively than those who have lived with diabetes for a longer period of time.

\section{Black tea}

Black tea is produced from the fresh leaves of Camellia sinensis. The different methods of preparing green tea and black tea may account for their differences. A global study has shown high black tea intake to be associated with a lower prevalence of type 2 diabetes. (Beresniak et al., 2012). Black tea might offer potential in managing diabetes (Zhang et al., 2008); the polysaccharides from black tea have free radical-scavenging activity. The major bioactive compounds of black tea (black tea polymerised polyphenol, BTPP) confer an antioxidant property (Leung et al., 2001).

Black tea has been reported to have both curative and preventive effect in induced diabetic rats (Gomes et al., 1995). In a recent study, Butacnum et al. (2017) examined the effect of black tea on postprandial blood glucose in both normal and pre-diabetic individuals. Black tea drinks significantly controlled postprandial blood glucose from sucrose taken 5 minutes previously. The black tea drink was made by extraction of black tea leaves by hot water, removing first caffeine and catechins. No significant difference was seen between high dose and low dose (220 mg BTPP and $110 \mathrm{mg}$ BTPP respectively) in postprandial glucose control (Butacnum et al., 2017). However, in type 2 diabetic mice, green tea had a greater blood glucose-lowering effect than black tea (Tang et al., 2013). The green tea extracts had $71.5 \%$ tea polyphenols which was mainly catechin and the black tea extracts had $83.7 \%$ total tea polyphenols (68.4\% theaflavins, $15.3 \%$ catechins). Tang et al. suggest green tea extracts exert their hypoglycaemic effect by decreasing insulin resistance while black tea extracts act by stimulating insulin secretion and maintaining $\beta$-cell function.

In contrast, Mackenzie et al. (2007) reported no hypoglycaemic effect for either green tea and black tea in adults with type 2 diabetes. There was no significant difference in the changes in glycosylated haemoglobin between the study groups (placebo, $375 \mathrm{mg}$ or $750 \mathrm{mg}$ green tea extract or black tea extract).

\section{Broccoli}

Broccoli (Brassica oleracea) is one of the vegetables that has exhibited hypoglycaemic properties in type 2 diabetic patients. It is reported to have a serum insulin-reducing effect in diabetic patients, improving insulin resistance (Bahadoran et al., 2012). In a clinical trial, broccoli sprouts powder was reported to have significantly ameliorated serum triglyceride and oxidized LDL/LDL-cholesterol ratio in type 2 diabetic patients (Bahadoran et al., 2012). Even HDL-cholesterol was higher in a group of 
participants that received a higher dose (10g/day) of the powder, resulting in a lower risk of cardiovascular disease (Hu et al., 2013). Cardiovascular disease is a complication for diabetic patients, since diabetes itself is a risk factor for the former condition. Some of the apparent health benefits of broccoli may be attributed to its protective effect against oxidative stress (Suresh et al., 2016). However, more research is needed to confidently associate broccoli to the reduction of high blood glucose and its complications in diabetics.

\section{Garlic}

Garlic (Allium sativum) has long been used for the treatment of many conditions related to the heart and circulation in both traditional and orthodox medicine. The compounds sulphur and allicin are said to be the substances found in garlic that are responsible for the hypoglycaemic properties of garlic (Mathew and Augusti, 1973).

Several scientists have studied garlic and its anti-diabetic effect in type 2 diabetic patients. In a singleblind and placebo-controlled study, conducted by Ashraf et al. (2011), which lasted for 24 weeks, the potential hypoglycaemic effect of extract of garlic was investigated in people with type 2 diabetes. The diabetic patients were randomised into two groups, each receiving either 300mg of garlic tablets three times a day or placebo. Both groups received metformin in addition (500mg twice/day). The intervention resulted in a $3 \%$ decrease in fasting blood glucose after 24 weeks compared to a $0.6 \%$ increase in the control group.

Precursors of garlic oil and allicin show significant anti-diabetic or hypoglycaemic effects in alloxan diabetic rats (Modak et al., 2007). Similarly, Jalal et al. (2007) reported a positive association between the intake of raw garlic and insulin resistance in diabetic rats.

Padiya et al. (2011) investigated the effect raw garlic has on type 2 diabetic rats. The garlic was effective in improving insulin sensitivity while attenuating metabolic syndrome and oxidative stress. In streptozotocin-induced diabetic rats, Lui et al. (2006) found that the use of garlic oil for a long period can have a beneficial effect on diabetics by improving oral glucose tolerance. Liu et al. (2005) found that garlic oil (100 mg/kg body weight) and diallyl trisulfide (40 mg/kg body weight) taken for 3 weeks improved glycaemic control in diabetic rats through increased insulin secretion and increased insulin sensitivity. Duncan (1999), in a randomised clinical study, reported that hyperglycaemia can be corrected with garlic oil. Most of these studies used garlic extracts; studies are needed to determine the quantity of raw garlic needed to provide anti-diabetic effect among humans.

\section{Moringa}

Studies have reported an anti-diabetic effect of Moringa oleifera leaves in diabetic rats. Moringa has been shown to reduce fasting blood glucose in normal $(<120 \mathrm{mg} / \mathrm{dL})$, mild $(120-300 \mathrm{mg} / \mathrm{dL})$ and severe diabetic $(>300 \mathrm{mg} / \mathrm{dL}$ ) rats but the effect was greater in severe diabetic rats (Jaiswal et al., 2009). It also improved glucose intolerance in type 2 diabetic rats (Ndong et al., 2007).

Moringa reduced the serum blood glucose levels of diabetic rats (Chen et al., 2007); hence it has a protective effect on streptozotocin-induced diabetic rats (Gupta et al., 2012). Edoga et al. (2013) have also reported a dose-dependent blood glucose-lowering effect in both normal and streptozotocininduced diabetic rats. The available evidence therefore, rates Moringa oleifera as one of the 
plants/herbs most likely to be useful in type 2 diabetics. Much more work needs to be done in humans to ascertain its anti-diabetic effects.

\section{Ginseng}

Ginseng (Panax sp) is found only in the Northern Hemisphere, in North America and in Eastern Asia and grows typically in cooler climates where the weather is favourable for its growth. Several studies have suggested it possesses some anti-diabetic effects in both type 1 and type 2 diabetes. According to Hui et al. (2009) the uptake of glucose by the muscle and adipose tissues, inhibition of glucose absorption in the intestine, increment in insulin secretion and inhibition of glucose production from hepatocytes, are the mechanisms through which ginseng is able to lower blood glucose of type 1 and 2 diabetic patients.

Similarly, Amin et al. (2011) reported a hypoglycaemic and diabetic preventive effect of Ginseng. In their study, male rats were used to investigate the mechanism by which Ginseng may infer a protective effect on diabetes. Male rats are more susceptible to diabetes than females. Aqueous extract of Ginseng appeared to have hypoglycaemic effects. Kang et al. (2008) also reported that ginseng has a significant effect in reducing serum glucose of diabetic rats.

\section{Guava}

Guava (Psidium guajava) is a tropical pear-shaped fruit. Using streptozotocin-induced diabetic rats, Shen et al. (2008) showed that aqueous and ethanolic extracts of guava leaves have hypoglycaemic effect (significant) in type 2 diabetic rats. Guava has been found to reduce serum blood glucose levels of streptozotocin-induced diabetic male mice (Yusof and Said, 2004). $250 \mathrm{mg} / \mathrm{kg}$ body weight $P$. guajava water extract showed greater hypoglycaemic and anti-diabetic effects as compared with 0.5 $\mathrm{mg} / \mathrm{kg}$ body weight glibenclamide, a sulfonylureas drug, in diabetic rats. Even when the extract was combined with $250 \mathrm{mg} / \mathrm{kg}$ Mangifera indica water extract, the effect was still strong (Rawi et al., 2011). Guava as a fruit is very high in dietary fibre, which has a positive effect on diabetes in terms of glycaemic control (Hindy et al., 2012; Meyer et al., 2000). More data are needed to understand the dose-dependent effects of guava and how the plant, leaves or fruits could be of benefit to diabetic patients.

\section{Onion}

Onion (Allium cepa), also known as the bulb onion, is a common vegetable in most parts of the world. It has been credited with anti-hyperglycaemic activity in diabetic rats. A. cepa, Brassica oleracea var. botrytis (Cauliflower) and A. sativum (Garlic) all had significant anti-diabetic effects by reducing the hyperglycaemic levels in rabbits (Roman-Ramos et al., 1995). Onion achieves this effect by normalizing the activities of liver glucose-6-phosphatase, HMG CoA as well as hexokinase, all found in the liver (Roman-Ramos et al., 1995; Kumari et al., 1995). According to Mathew et al. (1975), a dose of $50 \mathrm{~g}$ of onion juice was able to significantly control postprandial glucose levels when clinically offered to diabetic patients. However, a diabetic diet containing onion (12.5\% body weight) did not reduce blood glucose of diabetic rats after 15 days (Jelodar et al., 2005). It was suggested that volatile chemical substances in onion may have escaped during the processing of the diet. Thus, while onion may have hypoglycaemic effects, cooking might render it impotent; thus, processing methods that preserve the chemical substances in it should be investigated and encouraged. 
This finding does not suggest the intake of the chemical supplements. As single phytochemical may not have the same effects as the natural plant. For example, diabetic rats fed with $6 \%$ onion diet containing $0.023 \%$ quercetin had reduced blood glucose more than diabetic rats fed with quercetin aglycone alone $(0.023 \%)$ (Azuma et al., 2007). Even oxidative stress markers were higher in the quercetin group compared to the onion group. Quercetin, an active antioxidant in onion is more effective when consumed in onion than the same amount consumed alone.

The higher potency of onion compared to quercetin might be attributed to the additive or interactive effect of all the polyphenols onion contains (Jung et al., 2011). In diabetic rats, a high fat diet that contained $1 \%$ onion extract was generally more hypoglycaemic by improving insulin insensitivity than high fat diet with $0 \%$ onion extract, $0.5 \%$ onion extract, and even $0.1 \%$ quercetin which is equivalent to $1 \%$ of onion extract.

Onion is a very important vegetable used in the preparation and processing of food. Studies should be conducted to understand how phytochemicals interact with quercetin to produce a synergistic effect. The temperature at which this effect is annulled should be determined to inform diabetic patients and those at risk.

\section{Tiger Nut}

Tiger nuts (Cyperus esculentus) are commonly grown in parts of Africa. It can be eaten raw, roasted, baked, or made into a refreshing drink. It requires little or no processing before consumption, thus making it a cheap source of food for people. Chukwuma et al. (2010) report that extracts of tiger nut have blood glucose-lowering effect in normal people because of its high dietary fibre content.

\section{Bush Mango}

Bush mango (Irvingia gabonensis) is a long-lived indigenous tree that is native to the moist and tropical forest of Central and West Africa (Jamnadass et al., 2011). They are high in vitamin C and dietary fibre. Evans et al. (2014) found that daily consumption of bush mango among obese people improves blood glucose levels, suggesting a protective and/or curative effect. It has also been reported that bush mango peels have blood sugar lowering effect in diabetes-induced rats and also reduces urine sugar content because it contains high levels of soluble fibre (Gondi et al., 2015). This suggests that ripe bush mango peels may improve insulin sensitivity and/or improve its blood glucose-binding property.

\section{Okra}

Okra (Abelmoschus esculentus; also known as Hibiscus esculentus) is widely cultivated and eaten freshly cooked or in dry powder form in soups and stews. It has been reported that the peels and seeds reduce blood glucose in diabetic rats (Sabitha et al., 2011). A dose-response was seen when aqueous extract and dried powder of $A$. esculentus were administered for 14 days to diabetic rats reducing blood glucose (Ben-Chioma et al., 2015). Similarly, intake of $H$. esculentus seed powder, $2 \mathrm{~g} / \mathrm{kg}$ body weight, as well as $H$. esculentus purified mucilage ( $2 \mathrm{~g} / \mathrm{kg}$ bw/day) daily for 14 days improved blood glucose, lipid profile, insulin level and antioxidant activity in diabetes-induced rats, with the seeds showing greater effect (Hajian et al., 2016). Okra powder given to diabetic rats, $2 \mathrm{~g} / \mathrm{kg}$ body weight for 35 days reduced their blood glucose and improved antioxidant potential 
of the rats (Mishra et al., 2016). Tavafi (2016) suggests that okra seeds inhibit certain pathogenic pathways of diabetes. Antioxidant activity of okra seed and its flavonoid compounds is very important in inhibition of diabetes pathogenic pathways including inhibition of oxidative stress and inhibition of $\alpha$-glucosidases and $\alpha$-amylases. Okra extract ( $200 \mathrm{mg} / \mathrm{kg}$ body weight) has also shown to improve the conditions of gestational diabetes-induced rats (Tian et al., 2015) and highfat diet-induced rats (Fan et al., 2014).

Intake of okra may ameliorate blood glucose, lipid profile and other factors associated with diabetes in diabetes patients. It may be more beneficial to consume whole okra since both the seeds and mucilage have had effects in rat studies. However, the amount needed to effect hypoglycaemic and/or hyperlipidaemic effects in humans is unclear. It has been used by diabetic patients for many years, but future clinical studies are needed to measure its effects in diabetic patients.

\section{Dates}

Dates are found worldwide and much grown/cultivated in the Northern part of Africa and the Middle East where the soil is good for its growth (Besbes et al., 2009). Its fruits and seeds have been used in the prevention and treatment of diabetes (Bnouham et al., 2002). Hasan and Mohieldein (2016) evaluated the anti-diabetic, hypolipidemic and antioxidative effect of date seed extract on diabetesinduced rats. During the eight weeks of treatment with extract of the date seed, glucose levels were analysed weekly. Glycated haemoglobin and serum insulin tests were performed to evaluate the glycaemic effect of the extract on the diabetes-induced rats. There was a significant reduction in blood glucose levels of the diabetes-induced rats compared to the controls. The researchers also concluded that long term use/treatment with the extract restores liver and kidney function. Miller et al. (2003) also reported similar findings from their study which sought to measure the glycaemic responses of healthy individuals to the consumption of dates and dates with yogurt. The mechanism of action has not been determined and more research is needed to understand its mechanism in influencing body functions related to diabetes.

\section{Bitter Melon}

Bitter melon (Mamordica charantia) fruit, commonly known as the bitter melon or bitter gourd, is widely grown in tropic areas. Extracts of the fruit pulp, seeds, the leaves and the whole plant have been shown to have hypoglycaemic effect in various animal models (Modak et al., 2007). The fruit extract of bitter melon has also been reported by Sridhar et al. (2008) to improve insulin signalling and insulin sensitivity in rats fed with a high-fat diet. Further research is required to ascertain the influence of consumption frequency of bitter gourd on its potency in humans, if any. Fernandes et al. (2007) also reported a blood glucose lowering effect of bitter melon extract in alloxan-induced diabetic rats, though a high dose appeared to have been needed. The extract reduced blood glucose by increasing the uptake of glucose by hemidiaphragm and inhibited glycogenolysis in liver slices in-vitro.

\section{Dandelion}

Dandelion is a plant in the genus Taraxacum with yellow flower heads and broad-ended leaves. Though there is limited information on the use of dandelion in the treatment and management of type 2 diabetes ( Iddrisu et al., 2015), Nnamdi et al. (2012a) found that consumption of dandelion leaf and root reduced the blood sugar levels in type 2 induced diabetic rats. The roots were found to be more potent than the leaves in its hypoglycaemic effect. In a human study, type 2 diabetic patients were randomised into 3 
groups. The first and second groups were treated with $5 \mathrm{~g}$ of dandelion leaf and root powder respectively for 9 days. The third group did not receive treatment. Both leaves and roots reduced fasting blood glucose, but the roots proved to be more effective (Iddrisu et al., 2016).

\section{Watermelon}

Watermelon belongs to the genus Citrullus. The anti-diabetic effect of watermelon in vivo was studied using Imprinting Control Region (ICR) mice. The mice were induced with diabetes using streptozotocin and then supplemented with watermelon extract. The results showed a significant reduction in blood glucose and improvement in serum insulin levels. Further analysis showed that watermelon was effective in protecting pancreatic cell death (Ahn et al., 2011). Omigie and Agoreyo (2014) investigated the effect of watermelon seed extract on blood glucose concentrations and electrolyte parameters. The study used streptozotocin-induced diabetic rats and after a week of inducing diabetes in the rats, they were administered the watermelon seed extract ( $200 \mathrm{mg} / \mathrm{kg}$ body weight) orally for 29 days. There was a significant reduction in plasma blood glucose in rats treated with the watermelon seed extract compared to the diabetic control group. Muhammad et al. (2015) also investigated the anti-diabetic effect of watermelon seed extract in streptozotocin-induced diabetic albino rats. The rats were treated for 28 days with the watermelon seed extract $(200 \mathrm{mg} / \mathrm{kg}$ of body weight). This study also found a significant reduction in fasting blood glucose in the rats treated with the watermelon seed extract compared to the diabetic control group. The current evidence suggests that watermelon seeds contains a substance that might be able to induce the regeneration of the beta cells of the pancreas or improve insulin secretion and/or insulin function.

\section{Pumpkin}

Pumpkin (Cucurbita pepo) is a vegetable that is widely consumed across the world. Sedigheh et al. (2011) investigated the hypoglycaemic and hypolipidemic effects of pumpkin powder in alloxan-induced diabetic male rats. They reported a significant decrease in serum glucose and improvement in lipid profile in the pumpkin-treated group compared to the controls. Protein-bound polysaccharide from pumpkin (PBPP) was found to exert hypoglycaemic effects in alloxaninduced diabetic rats (Quanhong et al., 2005). There were also increased levels of serum insulin and an improvement in glucose tolerance among the treated group. Pumpkin Crude Extract has been reported to have a blood glucose-lowering effect in induced diabetic Kunming mice (Jin et al., 2013). In addition to its blood glucose-lowering effect, pumpkin powder was found to increase insulin levels in diabetic rats. The authors speculate that its consumption could have positive effects in preventing hyperglycaemia and histopathological changes of the pancreas (Somayeh et al., 2011). In another study, dietary pumpkins were effective in improving glucose tolerance in type 2 diabetic rats. It was suggested that the trigonelline and Nicotinic Acids in pumpkin were responsible for the glucose tolerance observed, though the effect was more in the case of trigonelline (Yoshinari et al., 2009).

\section{Mushrooms}

Mushrooms are fungi, and not plants. They are considered in this review because they grow on soils, on plants and among plants.

Mushroom is a delicacy in many cultures and in some geographical locations it's used as medicine or nutraceutical substance. Mushrooms, as functional foods, might have a particularly high potential 
impact for the prevention of diabetes, as well as curative properties for the condition more than other species (Perera and Li, 2011). A randomized placebo control study by Hsu et al. (2007) showed that 12 weeks of treatment with mushroom extract improved insulin resistance in patients, 20 to 75 years of age, who had had type 2 diabetes for more than one year. This beneficial effect of mushroom could be attributed to adiponectin concentration found in mushrooms; its consumption among people with high risk should be encouraged for prevention. Polysaccharides extracted from mushrooms also have demonstrated anti-diabetic effects. Polysaccharides from Pleurotus tuber-regium administered at the dose of $20 \mathrm{mg} / \mathrm{kg}$ body weight per day to diabetic rats for 8-week period reduced blood glucose concentrations, restored serum insulin levels and increased antioxidant activity (Huang et al., 2012). The aqueous extract of Pleurotus sajor-caju, another species of edible oyster mushroom, showed hypoglycaemic and antidiabetic effects after single and repeated oral administration in normal and diabetic rats (Ng et al., 2015). Doses of 500 to $1000 \mathrm{mg} / \mathrm{kg}$ all had a similar effect to $150 \mathrm{mg} / \mathrm{kg}$ of metformin in normal and diabetic rats. It might not be beneficial for diabetics and pre-diabetics to consume large quantities of mushrooms to ameliorate blood glucose. According to $\mathrm{Ng}$ et al, the dose of $750 \mathrm{mg} / \mathrm{kg}$ was most effective; it additionally had a weight reduction effect on the diabetic rats (Ng et al., 2015).

Mushrooms may be nutritious and medicinal; however, care must be taken when collecting the macro fungus. Some mushrooms are poisonous and/or fatal; a typical example being Amanita phalloides (commonly known as death cap). It is very important to identify the edible mushrooms. Species which are strange should be avoided until proven wholesome by chemical analysis. It is better to adhere to well-known mushrooms than trying out new ones which might contain toxins. Because there are so many different varieties, further research is needed to examine the impact of many of them on animals and if appropriate in human studies before we can make any blanket statement about mushrooms per se being useful in treatment of diabetes.

\section{CONCLUSION}

The non-pharmacological approach to the management of diabetes has been extensively studied using several plants and plant products, largely in animal models. The evidence provided by this review suggests the potentials that some of these agents have, not only for the treatment of diabetes but also for its prevention. Among the plants assessed in this paper for the evidence of treating diabetes, garlic had the strongest evidence in terms of its beneficial effect.

The terms 'treatment', 'treat', 'treating' as used in the paper only represents the care given to the patients. These foods or their products are not an alternative to the existing medications for managing diabetic patients; they may rather be complementary. More studies are required to determine the amount of active substances in plant foods and mushrooms needed in the management of diabetes; human trials should be begun where justified. 
Table 1. Summary of studies that investigated the use of some plants as anti-diabetic agents and their main findings

\begin{tabular}{|c|c|c|c|}
\hline Author(s) & Plant/Fruit & Study Aim & Main Findings (usually in animals) \\
\hline $\begin{array}{l}\text { Iddrisu et al. (2015); } \\
\text { Iddrisu et al. (2016); } \\
\text { Nnamdi et al. (2012) }\end{array}$ & Dandelion & $\begin{array}{l}\text { Determine the anti-diabetic } \\
\text { effect of dandelion leaves and } \\
\text { roots among type } 2 \text { diabetic } \\
\text { patients. }\end{array}$ & $\begin{array}{l}\text {-Consumption of dandelion leaves and roots } \\
\text { reduces blood glucose levels among type } 2 \\
\text { diabetic patients. } \\
\text {-The roots were found to be more effective in its } \\
\text { hypoglycaemic effect than the roots }\end{array}$ \\
\hline $\begin{array}{l}\text { Gomes et al. (1995) } \\
\text { Panagiotakos et al. (2009); } \\
\text { Igarashi et al. (2007); } \\
\text { Wolfram et al. (2006); } \\
\text { Sabu et al. (2002); } \\
\text { Haidaria et al. (2013); } \\
\text { The Inter Act Consortium } \\
\text { (2012); } \\
\text { Kao et al. (2006); } \\
\text { Toolsee et al. (2013); } \\
\text { Kang et al. (2012); } \\
\text { Mackenzie et al. (2007); } \\
\text { Leung et al. (2001); } \\
\text { Butacnum et al. (2017); } \\
\text { Beresniak et al. (2012); } \\
\text { Butacnum et al. (2017); } \\
\text { Tang et al. (2013) }\end{array}$ & $\begin{array}{l}\text { Tea } \\
\text { Black Tea } \\
\text { Green Tea }\end{array}$ & $\begin{array}{l}\text { To determine the link between } \\
\text { long term tea consumption } \\
\text { and the prevalence of type } 2 \\
\text { diabetes among adults } \\
\text { To evaluate the effect of: } \\
\text { black tea on diabetic-induced } \\
\text { rats } \\
\text { green tea consumption on } \\
\text { blood glucose and glycaemic } \\
\text { control }\end{array}$ & $\begin{array}{l}\text { Long term consumption of tea was associated } \\
\text { with reduced levels of blood glucose and } \\
\text { reduced prevalence of type } 2 \text { diabetes } \\
\text { Black tea possesses anti-diabetic properties as } \\
\text { extracts of black tea reduced the blood glucose } \\
\text { levels in the test rats } \\
\text {-It showed both preventive and curative } \\
\text { properties as well } \\
\text { Consumption of green tea: } \\
\text {-reduces and normalises serum glucose levels } \\
\text {-improves glycaemic control } \\
\text {-has glycaemic regulatory effect in pre-diabetic } \\
\text { patients } \\
\text {-has protective effect against diabetic } \\
\text { nephropathy in type } 2 \text { diabetic patients }\end{array}$ \\
\hline $\begin{array}{l}\text { Bahadoran et al. (2012); } \\
\text { Suresh et al. (2016); } \\
\text { Hu et al. (2013) }\end{array}$ & Broccoli & 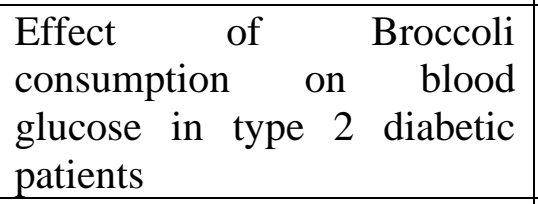 & $\begin{array}{l}\text {-Improves insulin resistance in type } 2 \text { diabetic } \\
\text { patients }\end{array}$ \\
\hline $\begin{array}{l}\text { Ashraf et al. (2011); } \\
\text { Modak et al. (2007); } \\
\text { Jalal et al. (2007); } \\
\text { Padiya et al. (2011); }\end{array}$ & Garlic & $\begin{array}{l}\text { To determine } \\
\text { hypoglycaemic effect of } \\
\text { extract of garlic was }\end{array}$ & $\begin{array}{l}\text {-Garlic has hypoglycaemic effect in patients } \\
\text { with type } 2 \text { diabetes mellitus } \\
\text { - Precursors of garlic oil and allicin showed } \\
\text { hypoglycaemic effects in alloxan diabetic rats }\end{array}$ \\
\hline
\end{tabular}




\begin{tabular}{|c|c|c|c|}
\hline $\begin{array}{l}\text { Duncan (1999); } \\
\text { Lui et al. (2006); } \\
\text { Liu et al. (2005); } \\
\text { Mathew and Augusti } \\
\text { (1973) }\end{array}$ & & $\begin{array}{l}\text { investigated in people with } \\
\text { type } 2 \text { diabetes }\end{array}$ & $\begin{array}{l}\text {-Consumption of raw garlic improves insulin } \\
\text { resistance in type } 2 \text { diabetic patients } \\
\text {-Improves oral glucose tolerance thus good for } \\
\text { the prevention and management of diabetes } \\
\text {-Corrects hyperglycaemia in type } 2 \text { diabetic } \\
\text { patients }\end{array}$ \\
\hline $\begin{array}{l}\text { Jaiswal et al. (2009); } \\
\text { Ndong et al. (2007); } \\
\text { Chen et al. (2007); } \\
\text { Gupta et al. (2012); } \\
\text { Edoga et al. (2013) }\end{array}$ & Moringa & $\begin{array}{l}\text { Anti-diabetic effect of } \\
\text { moringa in type } 2 \text { diabetic } \\
\text { patients }\end{array}$ & $\begin{array}{l}\text {-Reduces fasting and serum blood glucose in } \\
\text { type } 2 \text { diabetic rats as well normal rats. }\end{array}$ \\
\hline $\begin{array}{l}\text { Hui et al. (2009); } \\
\text { Amin et al. (2011); } \\
\text { Kang et al. (2008) }\end{array}$ & Ginseng & $\begin{array}{l}\text { Hypoglycaemic effect of } \\
\text { Ginseng in diabetic patients }\end{array}$ & $\begin{array}{l}\text {-Lowers blood glucose of both type } 1 \text { and type } 2 \\
\text { diabetic patients } \\
\text {-Has hypoglycaemic effect in type } 2 \text { diabetic } \\
\text { patients. }\end{array}$ \\
\hline $\begin{array}{l}\text { Shen et al. (2008); } \\
\text { Hindy et al. (2012); } \\
\text { Meyer et al. (2000); } \\
\text { Yusof and Said (2004); } \\
\text { Rawi et al. (2011) }\end{array}$ & Guava & $\begin{array}{l}\text { Hypoglycaemic effect of } \\
\text { extracts of guava/leaves in } \\
\text { streptozotocin-induced rats }\end{array}$ & $\begin{array}{l}\text {-Reduction of serum blood glucose levels in } \\
\text { streptozotocin-induced diabetic rats } \\
\text {-Has hypoglycaemic effect in streptozotocin- } \\
\text { induced diabetic rats }\end{array}$ \\
\hline $\begin{array}{l}\text { Azuma et al. (2006); } \\
\text { Roman-Ramos et al. } \\
\text { (1995); Kumari et al. } \\
\text { (1995); } \\
\text { Mathew et al. (1975); } \\
\text { Jelodar et al. (2005) }\end{array}$ & Onion & $\begin{array}{l}\text { Anti-diabetic properties of } \\
\text { onion in type } 2 \text { diabetic } \\
\text { patients }\end{array}$ & $\begin{array}{l}\text {-Possesses hypoglycaemic properties } \\
\text {-Control post-prandial glucose in type } 2 \text { diabetic } \\
\text { patients }\end{array}$ \\
\hline $\begin{array}{l}\text { Modak et al. (2007); } \\
\text { Sridhar et al. (2008); } \\
\text { Fernandes et al. (2007) }\end{array}$ & $\begin{array}{l}\text { Bitter melon } \\
\text { fruit }\end{array}$ & $\begin{array}{l}\text { Effect of bitter melon fruit } \\
\text { extracts on blood glucose in } \\
\text { induced-diabetic rats }\end{array}$ & $\begin{array}{l}\text { - Extract of bitter melon has blood glucose } \\
\text { lowering effect in alloxan induced diabetic rats } \\
\text { - It improves insulin signalling and insulin } \\
\text { sensitivity in rats fed with high-fat diet }\end{array}$ \\
\hline
\end{tabular}




\begin{tabular}{|c|c|c|c|}
\hline $\begin{array}{l}\text { Besbes et al. (2009); } \\
\text { Bnouham et al. (2002); } \\
\text { Hassan and Mohieldein } \\
\text { (2016); Miller (2003) }\end{array}$ & Date & $\begin{array}{l}\text { Anti-diabetic and anti- } \\
\text { lipidemic effect of dates }\end{array}$ & $\begin{array}{l}\text {-Significant reduction in blood glucose levels of } \\
\text { diabetes-induced rats } \\
\text {-Long term use restores liver and kidney } \\
\text { functions. }\end{array}$ \\
\hline $\begin{array}{l}\text { Sedigheh et al. (2011); } \\
\text { Quanhong et al. (2005); } \\
\text { Yoshinari et al. (2014); } \\
\text { Jin et al. . (2013); } \\
\text { Somayeh et al. (2011) }\end{array}$ & Pumpkin & $\begin{array}{l}\text { Hypoglycaemic } r \text { and } \\
\text { hypolipidemic effect of } \\
\text { pumpkin on alloxan-induced } \\
\text { diabetic rats. }\end{array}$ & $\begin{array}{l}\text {-Reduces blood sugar } \\
\text {-Improves glucose tolerance } \\
\text {-Increase serum insulin levels } \\
\text {-Improves lipid profile }\end{array}$ \\
\hline $\begin{array}{l}\text { Ahn et al. (2011); } \\
\text { Omigie and Agoreyo } \\
\text { (2014); Muhammad et al. } \\
\text { (2015). }\end{array}$ & Watermelon & $\begin{array}{l}\text { Effect of watermelon on } \\
\text { blood glucose concentration } \\
\text { and electrolyte concentration }\end{array}$ & $\begin{array}{l}\text { Watermelon seed extract has significant } \\
\text { reduction in plasma glucose concentration and } \\
\text { improve electrolyte balance. }\end{array}$ \\
\hline $\begin{array}{l}\text { Chukwuma et al. (2010); } \\
\text { Ekeanyanwu and } \\
\text { Ononogbu (2010); } \\
\text { Adejuyitan (2011); } \\
\text { Adejuyitan, (2009) }\end{array}$ & Tiger Nut & $\begin{array}{l}\text { Effect of tiger nut on blood } \\
\text { glucose and cardiovascular } \\
\text { health }\end{array}$ & $\begin{array}{l}\text {-Reduces blood glucose levels } \\
\text {-Have protective effect against cardiovascular } \\
\text { diseases and some cancers }\end{array}$ \\
\hline $\begin{array}{l}\text { Sabitha et al. (2011); } \\
\text { Ben-Chioma et al. (2015); } \\
\text { Hajian et al. (2016); } \\
\text { Mishra et al. (2016); } \\
\text { Tavafi (2016); } \\
\text { Tian et al. (2015); } \\
\text { Fan et al. (2014). }\end{array}$ & Okra & $\begin{array}{l}\text { Anti-diabetic effect of Okra in } \\
\text { diabetic rats. }\end{array}$ & $\begin{array}{l}\text { Okra peels and seeds was reported to reduce } \\
\text { blood glucose levels of diabetic induced rats. } \\
\text { It improves diabetic conditions of gestational } \\
\text { diabetic rats. }\end{array}$ \\
\hline $\begin{array}{l}\text { Evans et al. (2014); } \\
\text { Gondi et al. (2015); } \\
\text { Jamnadass et al. (2011) }\end{array}$ & Bush Mango & $\begin{array}{l}\text { The effect of mango } \\
\text { consumption in obese people } \\
\text { and the anti-diabetic effect of } \\
\text { mango peels in diabetic rats. }\end{array}$ & $\begin{array}{l}\text { Consumption of mango lowers blood glucose of } \\
\text { obese people. } \\
\text {-Mango peels reduce blood glucose due to its } \\
\text { high content of soluble fibre. }\end{array}$ \\
\hline
\end{tabular}




\section{REFERENCES}

Adejuyitan JA, Otunola ET, Akande EA, et al. 2009. Some physicochemical properties of flour obtained from fermentation of tigernut (Cyperus esculentus) sourced from a market in Ogbomoso, Nigeria. Afr J Food Sci 3(2):51-55. https://academicjournals.org/journal/AJFS/article-full-text-pdf/167227020072

Adejuyitan JA. 2011. Tiger nut processing: its food uses and health benefits. American Journal of Food Technology 6(3):197-201. https://doi.org/10.3923/ajft.2011.197.201

Ahn J, Choi W, Kim S, et al. 2011. Anti-diabetic effect of watermelon (Citrullus vulgaris Schrad) on Streptozotocin-induced diabetic mice. Food Sci Biotechnol 20:251-254. https://doi.org/10.1007/s10068-011-0034-5

Amin KA, Awad EM, Nagy MA. 2011. Effects of panax quinquefolium on streptozotocininduced diabetic rats: role of C-peptide, nitric oxide and oxidative stress. Int J Clin Exp Med 4(2):136-147. https://www.ncbi.nlm.nih.gov/pmc/articles/PMC3115382/

Ashraf R, Khan AR, Ashraf I. 2011. Garlic (Allium sativum) supplementation with standard antidiabetic agent provides better diabetic control in type 2 diabetes patients. Pak J Pharm Sci 24(4):565-570. https://www.ncbi.nlm.nih.gov/pubmed/21959822

Azuma K, Minami Y, Ippoushi K, Terao J. 2007. Lowering effects of onion intake on oxidative stress biomarkers in streptozotocin-induced diabetic rats. J Clin Biochem Nutr 40(2):131-140. https://doi.org/10.3164/jcbn.40.131

Bahadoran Z, Mirmiran P, Hosseinpanah F, et al. 2012. Broccoli sprouts powder could improve serum triglyceride and oxidized LDL/LDL-cholesterol ratio in type 2 diabetic patients: a randomized double-blind placebo-controlled clinical trial. Diabetes Res Clin Pract 96(3):348-54. https://doi.org/10.1016/j.diabres.2012.01.009

Ben-Chioma AE, Tamuno-Emine DG, Dan DB. 2015. The effect of Abelmoschus esculentus in alloxan induced diabetic wistar rat. International Journal of Science and Research 4(11):540-543. https://www.researchgate.net/profile/Adline_Ben-Chioma/publication/283580317

Beresniak, A., Duru, G., Berger, G., Bremond-Gignac, D. (2012). Relationships between black tea consumption and key health indicators in the world: an ecological study. BMJ Open 8(2): e000648. https://doi.org/10.1136/bmjopen-2011-000648

Besbes S, Drira L, Blecker C, et al. 2009. Adding value to hard date (Phoenix dactylifera L.): compositional, functional and sensory characteristics of date jam. Food Chemistry 112:406-411. https://doi.org/10.1016/j.foodchem.2008.05.093 
Bnouham M, Mekhfi H, Legssyer AK, Ziyyat A. 2002. Ethnopharmacology Forum: Medicinal plants used in the treatment of diabetes in Morocco. Int J Diabetes \& Metabolism 10:33-50. https://www.researchgate.net/publication/228700810

Butacnum A, Chongsuwat R, Bumrungpert A. 2017. Black tea consumption improves postprandial glycemic control in normal and pre-diabetic subjects: a randomized, double-blind, placebo-controlled crossover study. Asia Pac J Clin Nutr 26(1):59-64. https://doi.org/10.6133/apjcn.112015.08

Chen R, Zhu B, Wang Y, Liu Z. 2007. Extraction and Hypoglycemic effect of the total flavonoid from leaves of Moringa oleifera. J Food Sci Biotechnol 26(4):42-45.

https://doi.org/10.3321/j.issn:1673-1689.2007.04.009

Chukwuma ER, Obioma N, Christopher OI. 2010. The phytochemical composition and some biochemical effects of Nigerian tigernut (Cyperus esculentus L.) tuber. Pak J Nutr 9(7):709-715. https://doi.org/10.3923/pjn.2010.709.715

Duncan MG. 1999. The effects of nutritional supplements on the treatment of depression, diabetes, and hypercholesterolemia in the renal patient. J Renal Nutr 9(2):58-62. https://doi.org/10.1016/s1051-2276(99)90001-8

Edoga CO, Njoku OO, Amadi EN, Okeke JJ. 2013. Blood sugar lowering effect of Moringa oleifera Lam in albino rats. Int J Sci Technol 3(1):88-90. https://pdfs.semanticscholar.org/5453/ac494e374182111469e32d08038094125450.pdf

Ekeanyanwu RC, Ononogbu CI. 2010. Nutrititive value of Nigerian Tigernut (Cyperus esculentus L.). Agricultural Journal 5(5):297-302. https://doi.org/10.3923/aj.2010.297.302

Evans FS, Meister M, Mahmood M, et al. 2014. Mango supplementation improves blood glucose in obese individuals. Nutrition and Metabolic Insights 7:77-84. https://doi.org/10.4137/NMI.S17028

Fan S, Yu Z, Sun Q, et al. 2014. Extract of okra lowers blood glucose and serum lipids in highfat diet-induced obese C57BL/6 mice. The Journal of Nutritional Biochemistry 25(7):702-709. https://doi.org/10.1016/j.jnutbio.2014.02.010

Fernandes NPC, Lagishetty CV, Panda VS, Naik RS. 2007. An experimental evaluation of the antidiabetic and antilipidemic properties of a standardized Momordica charantia fruit extract. BMC Complement Altern Med 7:29. https://doi.org/10.1186/1472-6882-7-29

Gomes A, Vedasiromoni JR, Das M, et al. 1995. Anti-hyperglycemic effect of black tea (Camellia sinensis) in rat. J Ethnopharmacol 45(3):223-226. https://doi.org/10.1016/03788741(95)01223-Z 
Gondi M, Basha SA, Bhaskar JJ, et al. 2015. Anti-diabetic effect of dietary mango (Mangifera indica L.) peel in streptozotocin-induced diabetic rats. J Sci Food Agric 95(5):991-9. https://doi.org/10.1002/jsfa.6778

Gupta R, Mathur M, Bajaj VK. 2012. Evaluation of antidiabetic and antioxidant activity of Moringa oleifera in experimental diabetes. J Diabetes 4(2):164-71.

https://doi.org/10.1111/j.1753-0407.2011.00173.x.

Haidari F, Omidian K, Rafiei H, et al. 2013. Green tea (Camellia sinensis) supplementation to diabetic rats improves serum and hepatic oxidative stress markers. Iran J Pharm Res 12(1):109114. https://www.ncbi.nlm.nih.gov/pubmed/24250578

Hajian S, Asgary S, Rafieian-Kopaei M, et al. 2016. Hibiscus esculentus seed and mucilage beneficial effects in reducing complications of diabetes in streptozotocin-induced diabetic rats. Ann Res Antioxid 1(2):e23. http://annresantioxidants.com/index.php/ARA/article/view/92/136

Hasan M, Moheildein A. 2016. In vivo evaluation of anti-diabetic, hypolipidemic, antioxidative activities of Saudi date seed extract on streptozotocin induced diabetic rats. J Clin Diagn Res 10(3):FF06-12. https://doi.org/10.7860/JCDR/2016/16879.7419

Hindy G, Sonestedt E, Ericson U, et al. 2012. Role of TCF7L2 risk variant and dietary fibre intake on incident type 2 diabetes. Diabetologia 55(10):2646-2654.

https://doi.org/10.1007/s00125-012-2634-x

Hsu CH, Liao YL, Lin SC. 2007. The mushroom Agaricus Blazei Murill in combination with metformin and gliclazide improves insulin resistance in type 2 diabetes: a randomized, doubleblinded, and placebo-controlled clinical trial. J Altern Complement Med 13(1):97-102. https://doi.org/10.1089/acm.2006.6054

Hu G, Cui Y, Jousilahti P, et al. 2013. Joint effect of high-density lipoprotein cholesterol and low-density lipoprotein cholesterol on the risk of coronary heart disease. Eur J Prev Cardiol 20(1):89-97. https://doi.org/10.1177/1741826711428242

Huang H-Y, Korivi M, Chaing Y-Y, et al. 2012. Pleurotus tuber-regium polysaccharides attenuate hyperglycemia and oxidative stress in experimental diabetic rats. Evidence-Based Complementary and Alternative Medicine 2012: Article ID 856381.

https://doi.org/10.1155/2012/856381

Hui H, Tang G, Go VL. 2009. Hypoglycemic herbs and their action mechanisms. Chin Med 4:11. https://doi.org/10.1186/1749-8546-4-11

Iddrisu I, Oduro I, Tandoh MA. 2016. The effect of dandelion leaves and roots on blood glucose in type 2 diabetic patients. Journal of Nutritional Ecology and Food Research 3(2):125-132 https://doi.org/10.1166/jnef.2016.1128 
Iddrisu I, Oduro I, Tandoh MA, Annan A. 2015. Anti-diabetic effect of dandelion leaves and roots in type 2 diabetic patients - a systematic review. Nutrition \& Food Science 45(3):479-492. https://doi.org/10.1108/NFS-01-2015-0001

Igarashi K, Honma K, Yoshinari O, et al. 2007. Effects of dietary catechins on glucose tolerance, blood pressure and oxidative status in Goto-Kakizaki rats. J Nutr Sc. Vitaminol 53(6):496-500. https://doi.org/10.3177/jnsv.53.496

Jaiswal D, Kumar RP, Kumar A, et al. 2009. Effect of Moringa oleifera Lam. leaves aqueous extract therapy on hyperglycemic rats. J Ethnopharmacol 123(3):392-396 https://doi.org/10.1016/j.jep.2009.03.036

Jalal R, Bagheri SM, Moghimi A, Rasuli MB. 2007. Hypoglycemic effect of aqueous shallot and garlic extracts in rats with fructose-induced insulin resistance. J Clin Biochem Nutr 41(3):218223. https://doi.org/10.3164/jcbn.2007031.

Jamnadass RH, Dawson IK, Franzel S, et al. 2011. Improving livelihoods and nutrition in SubSaharan Africa through the promotion of indigenous and exotic fruit production in smallholders' agroforestry systems: A review. International Forest Review 13:338-354. http://dx.doi.org/10.1505/146554811798293836

Jelodar GA, Maleki M, Motadayen MH, Sirus S. 2005. Effect of fenugreek, onion and garlic on blood glucose and histopathology of pancreas of alloxan-induced diabetic rats. Indian J Med Sci 59(2): 64-69. https://doi.org/10.4103/0019-5359.13905

Jia W, Gao W, Tang L. 2003. Antidiabetic herbal drugs officially approved in China. Phytother Res 17(10):1127-1134. https://doi.org/10.1002/ptr.1398

Jin H, Zhang Y-J, Jiang J-X, et al. 2013. Studies on the extraction of pumpkin components and their biological effects on blood glucose of diabetic mice. Journal of Food and Drug Analysis. 21(2):184-189. https://doi.org/10.1016/j.jfda.2013.05.009

Jung JY, Lim Y, Moon MS, et al. 2011. Onion peel extracts ameliorate hyperglycemia and insulin resistance in high fat diet/streptozotocin-induced diabetic rats. Nutrition \& Metabolism 8(1):18-15. https://doi.org/10.1186/1743-7075-8-18

Kang KS, Yamabe N, Kim HY, et al. 2008. Therapeutic potential of 20(S)-ginsenoside Rg(3) against streptozotocin-induced diabetic renal damage in rats. Eur J Pharmacol 591(1-3):266-272. https://doi.org/10.1016/j.ejphar.2008.06.077

Kang MY, Park YH, Kim BS, et al. 2012. Preventive effects of green tea (Camellia sinensis var. assamica) on diabetic nephropathy. Yonsei Med J 53(1):138-144. https://doi.org/10.3349/ymj.2012.53.1.138

Kao Y-H, Chang, H-H, Lee MJ, et al. 2006. Tea, obesity, and diabetes. Mol Nutr Food Res 50(2):188-210. https://doi.org/10.1002/mnfr.200500109 
Kumari K, Mathew BC, Augusti KT. 1995. Antidiabetic and hypolipidemic effects of S-methyl cysteine sulfoxide isolated from Allium cepa Linn. Indian J Biochem Biophys 32(1):49-54. https://www.ncbi.nlm.nih.gov/pubmed/7665195

Leung LK, Su Y, Chen R, et al. 2001. Theaflavins in black tea and catechins in green tea are equally effective antioxidants. J Nutr 131(9):2248 -2251. https://doi.org/10.1093/jn/131.9.2248

Liu CT, Hse H, Lii CK, et al. 2005. Effects of garlic oil and diallyl trisulfide on glycemic control in diabetic rats. Eur J Pharmacol 516(2):165-73. https://doi.org/10.1016/j.ejphar.2005.04.031

Liu CT, Wong PL, Lii CK, et al. 2006. Antidiabetic effect of garlic oil but not diallyl disulfide in rats with streptozotocin-induced diabetes. Food Chem Toxicol 44(8):1377-1384. https://doi.org/10.1016/j.fct.2005.07.013

Mackenzie T, Leary L, Brooks WB. 2007. The effect of an extract of green and black tea on glucose control in adults with type 2 diabetes mellitus: double-blind randomized study. Metabolism 56(10):1340-1344. https://doi.org/10.1016/j.metabol.2007.05.018

Mathew PT, Augusti KT. 1973. Studies on the effect of allicin (diallyl disulphide-oxide) on alloxan diabetes. I. Hypoglycaemic action and enhancement of serum insulin effect and glycogen synthesis. Indian J Biochem Biophys 10(3):209-212. https://www.ncbi.nlm.nih.gov/pubmed/4792931

Mathew PT, Augusti KT. 1975. Hypoglycaemic effects of onion, Allium cepa Linn. on diabetes mellitus - a preliminary report. Ind J Physiol Pharmacol 19(4):213-217. https://www.ncbi.nlm.nih.gov/pubmed/1223000

Meyer KA, Kushi LH, Jacobs DR Jr. 2000. Carbohydrates, dietary fiber, and incident type 2 diabetes in older women. Am J Clin Nutr 71(4):921-30. https://doi.org/10.1093/ajcn/71.4.921

Miller, C J, Dunn E V and Hashim I B. The glycaemic index of dates and date/yoghurt mixed meals. Are dates 'the candy that grows on trees'? Eur J Clin Nutr 57(3):427-30. https://doi.org/10.1038/sj.ejcn.1601565

Mishra N, Kumar D, Rizvi SI. 2016. Protective Effect of Abelmoschus esculentus against Alloxan-induced diabetes in Wistar strain rats. J Diet Suppl 13(6):634-46. https://doi.org/10.3109/19390211.2016.1164787

Modak M, Dixit P, Londhe J, et al. 2007. Indian herbs and herbal drugs used for the treatment of diabetes. J Clin Biochem.Nutr 40(3):163-173. https://doi.org/10.3164/jcbn.40.163

Modaresi M, Resalatpour N. 2012. The Effect of Taraxacum officinale hydroalcoholic extract on blood cells in mice. Adv Hematol 2012:653412. https://doi.org/10.1155/2012/653412 
Muhammad Y, Saidu AY, Muazu S, et al. 2015. Effects of watermelon seed extracts on fasting lipid profile in streptozocin induced diabetic albino rats. International Journal of Interdisciplinary Research and Innovations. 3(4): 81-84. http://www.researchpublish.com/download.php?file=Effects\%20of\%20Watermelon2526.pdf\&act=book

Ndong M, Uehara M, Katsumata S, et al. 2007. Effects of oral administration of Moringa oleifera Lam on glucose tolerance in Goto-Kakizaki and Wistar rats. J Clin Biochem Nutr 40(3):229-233. https://doi.org/10.3164/jcbn.40.229

Ng SH, Mohd Zain MS, Zakaria F, et al. 2015. Hypoglycemic and antidiabetic effect of Pleurotus sajor-caju aqueous extract in normal and streptozotocin-induced diabetic rats. Biomed Res Int. 2015:214918. https://doi.org/10.1155/2015/214918

Nnamdi CC, Uwakwe A, Chuku L. 2012a. Effect of aqueous and ethanolic extracts of dandelion (Taraxacum Officinale F.H. Wigg.) leaves and roots on some heamatological parameters of normal and STZ-inducesed diabetic wistar albino rats. Global Journal of Research on Medicinal Plants \& Indigenous Medicine 1(5):172-180. https://search.proquest.com/openview/5f2e2e1bbeb168ca8ac4a7b9278f0cee/1?pqorigsite $=$ gscholar $\& \mathrm{cbl}=2026661$

Nnamdi CC, Uwakwe A, Chuku L. 2012b. Hypoglycaemic effects of aqueous and ethanolic extracts of dandelion (Taraxacum Officinale Fh Wigg.) leaves and roots on streptozotocininduced albino rats. Global Journal of Research on Medicinal Plants \& Indigenous Medicine 1(6):211-217.

O'Donnell O. 2007. Access to health care in developing countries: breaking down demand side barriers. Cad Saude Publica 23(12):2820-2834. https://doi.org/10.1590/s0102$\underline{311 x 2007001200003}$

Omigie IO, Agoreyo FO. 2014. Effects of watermelon (Citrullus lanatus) seed on blood glucose and electrolyte parameters in diabetic wistar rats. Journal of Applied Science Environment 18(12): 231-233. https://doi.org/10.4314/jasem.v18i2.12

Padiya R, Khatua TN, Bagul PK, et al. 2011. Garlic improves insulin sensitivity and associated metabolic syndromes in fructose fed rats. Nutr Metab (Lond) 8:53. https://doi.org/10.1186/1743$\underline{7075-8-53}$

Panagiotakos DB, Lionis C, Zeimbekis A, et al. 2009. Long-term tea intake is associated with reduced prevalence of (type 2) diabetes mellitus among elderly people from Mediterranean islands: MEDIS Epidemiological Study. Yonsei Med. J 50(1):31- 38. https://doi.org/10.3349/ymj.2009.50.1.31

Perera PK, Li Y. 2011. Mushrooms as a functional food mediator in Preventing and ameliorating diabetes. Functional Foods in Health and Diseases. 1(4):161-171. https://doi.org/10.31989/ffhd.v1i4.133 
Ponnusamy S, Ravindran R, Zinjarde S, et al. 2011. Evaluation of traditional Indian antidiabetic medicinal plants for human pancreatic amylase inhibitory effect in vitro. Evid Based Complement Alternat Med 2011:515647. https://doi.org/10.1155/2011/515647

Quanhong L, Caili F, Yukui R, et al. 2005. Effects of protein-bound polysaccharide isolated from pumpkin on insulin in diabetic rats. Plant Foods Hum Nutr 60(1):13-16. https://doi.org/10.1007/s11130-005-2536-X

Rawi SM, Mourad IM, Sayed DA. 2011. Biochemical changes in experimental diabetes before and after treatment with mangifera indica and psidium guava extracts. Int J Pharm Biomed Sci 2(2):29-41. https://www.researchgate.net/publication/261834683.

Roman-Ramos R, Flores-Saenz JL, Alarcon-Aguilar FJ. 1995. Anti-hyperglycemic effect of some edible plants. J Ethnopharmacol 48(1):25-32.

https://doi.org/10.1016/0378-8741(95)01279-m

Sabitha V, Ramachandran S, Naveen KR, et al. 2011. Antidiabetic and antihyperlipidemic potential of Abelmoschus esculentus (L.) Moench. in streptozotocin-induced diabetic rats. J Pharm Bioallied Sci 3(3):397-402. https://doi.org/10.4103/0975-7406.84447

Sabu MC, Smitha K, Kuttan R. 2002. Anti-diabetic activity of green tea polyphenols and their role in reducing oxidative stress in experimental diabetes. J Ethnopharmacol 83(1-2):109-116. https://doi.org/10.1016/s0378-8741(02)00217-9

Sedigheh A, Jamal MS, Mahbubeh S, et al. 2011. Hypoglycaemic and hypolipidemic effects of pumpkin (Cucurbita pepo L.) on alloxan-induced diabetic rats. African Journal of Pharmacy and Pharmacology 5(23):2620-2626. https://doi.org/10.5897/AJPP11.635

Shen, SC, Cheng FC, Wu NJ. 2008. Effect of guava (Psidium guajava Linn.) leaf soluble solids on glucose metabolism in type 2 diabetic rats. Phytother Res 22(11):1458-1464.

https://doi.org/10.1002/ptr.2476

Somayeh K., Sedigheh A., Seyed J.M., Mahmoud R., Parvin M. (2011) Preventive effect of pumpkin (Cucurbita Pepo L.) on diabetic index and histopathology of pancreas in alloxaninduced diabetes in rats. Journal of Isfahan Medical School. 28(117):1108-1117. https://www.sid.ir/en/journal/ViewPaper.aspx?ID=221150

Sridhar MG, Vinayagamoorthi R, Arul Suyambunathan V, et al. 2008. Bitter gourd (Momordica charantia) improves insulin sensitivity by increasing skeletal muscle insulin-stimulated IRS-1 tyrosine phosphorylation in high-fat-fed rats. Br J Nutr 99(4):806-812. https://doi.org/10.1017/S000711450783176X

Suresh S, Waly MI, Guizani N, et al. 2016. Broccoli (Brassica oleracea) extract combats streptozotocin-induced diabetes and oxidative stress in rats. The FASEB Journal 30(1):404.6 https://www.fasebj.org/doi/abs/10.1096/fasebj.30.1_supplement.404.6 
Tang W, Li S, Liu Y, et al. 2013. Anti-diabetic activity of chemically profiled green tea and black tea extracts in a type 2 diabetes mice model via different mechanisms. Journal of Functional Foods 5(4):1784 -1793. https://doi.org/10.1016/j.jff.2013.08.007

Tavafi M. 2016. Hibiscus esculentus against hyperglycemia and dyslipidemia. Ann Res Antioxid 1(2):e26. http://annresantioxidants.com/index.php/ARA/article/view/95

The InterAct Consortium 2012. Tea Consumption and Incidence of Type 2 Diabetes in Europe: The EPIC-InterAct Case-Cohort Study. PLoS ONE 7(5):e36910. https://doi.org/10.1371/journal.pone.0036910

Tian ZH, Miao FT, Zhang X, et al. 2015. Therapeutic effect of okra extract on gestational diabetes mellitus rats induced by streptozotocin. Asian Pac J Trop Med 8(12):1038-1042. https://doi.org/10.1016/j.apjtm.2015.11.002

Toolsee NA, Aruoma OI, Gunness TK, et al. 2013. Effectiveness of green tea in a randomized human cohort: relevance to diabetes and its complications. Hindawi Biomed Res Int 2013:412379. https://doi.org/10.1155/2013/412379

Wolfram S, Raederstorff D, Preller M, et al. 2006. Epigallocatechin gallate supplementation alleviates diabetes in rodents. J Nutr 136(10):2512-2518. https://doi.org/10.1093/jn/136.10.2512

Yoshinari O, Sato H, Igarashi K. 2009 Anti-diabetic effects of pumpkin and its components, trigonelline and nicotinic acid, on Goto-kakizaki rats, Biosci Biotechnol Biochem 73(5):103310941. https://doi.org/10.1271/bbb.80805

Yusof RM, Said M. 2004. Effect of high fibre fruit (Guava - psidium guajava L.) on the serum glucose level in induced diabetic mice. Asia Pacific Journal of Clinical Nutrition 13:S135. http://search.ebscohost.com/login.aspx?direct=true\&db=a9h\&AN=34013634\&site=eds-live

Zhang J, Kang MJ, Kim MJ, et al. 2008. Pancreatic lipase inhibitory activity of taraxacum officinale in vitro and in vivo. Nutr Res Pract 2(4):200-203. https://doi.org/10.4162/nrp.2008.2.4.200 